Fecha de recepción: julio 2021 Fecha de aprobación: agosto 2021 Fecha publicación: septiembre 2021

\section{From light microscopy to X-ray microtomography: observation and analysis technologies in transdisciplinary approaches for bionic design and botany}

Felipe Luis Palombini ${ }^{(1)}$, Mariana Kuhl Cidade ${ }^{(2)}$, Branca Freitas de Oliveira ${ }^{(3)}$ and Jorge Ernesto de Araujo Mariath ${ }^{(4)}$

\begin{abstract}
Recent achievements in bioinspired designs closely follow growing advances in observation technologies which are essential for comprehending a biological structure or system and correctly adapting them in a project. Likewise, different areas of classical disciplines, such as plant sciences, are even being rewritten thanks to the progress of newer technologies. This paper addresses the impact the use of observation technologies has on the development of state-of-the-art botany research as well as its applications in bionic designs. From light microscopy $(\mathrm{LM})$ to X-ray microtomography $(\mu \mathrm{CT})$, we present examples of how multiple technologies are contributing to innovations and newer discoveries in plant morphology and anatomy, answering important questions about structure/ function. The evolution of observation technologies is discussed, showing how they are impacting the comprehension of multiple plant characteristics and their consequential adaptation and use in bioinspired projects by examples. Essentially, the transdisciplinary approach of connecting professionals from multiple fields is considered essential for the progress obtained both in bionics and botany. By including newer observation technologies in their research workflow, designers and botanists could benefit from different perspectives in the investigation and application of their findings.
\end{abstract}

Keywords: Design - Technology - Bionics - Biomimetics - Finite element analysis - X-ray microtomography - Light microscopy - Plant anatomy - Plant morphology - Creative processes

[Abstracts in spanish and portuguese at pages 73-74]

(1) Felipe Luis Palombini is graduated in Product Design and received his M.Sc. and his Ph.D. in the Graduate Program in Design (PGDesign), in the School of Engineering of the Federal University of Rio Grande do Sul (UFRGS), in Porto Alegre (Brazil). His research focused on biomimetic and bionic systems, including microstructural characterization and thermomechanical analyses of plants and natural materials, particularly bamboo (Bambusoideae) and bromeliads (Bromeliaceae), using high-resolution X-ray microtomography and Finite Element Analysis. He is associated with the Design and Computer Simulation Research Group (DSC/CNPq) and the Plant Anatomy Laboratory (LAVeg) at 
UFRGS and has worked as an Assistant Professor at the Federal University of Santa Maria (UFSM), Brazil. felipe.l.palombini@gmail.com

(2) Mariana Kuhl Cidade. Adjunct Professor in the Department of Industrial Design at the Federal University of Santa Maria (UFSM), in Santa Maria (Brazil). Mariana Cidade is graduated in Industrial Design and received her M.Sc. and her Ph.D. in the Graduate Program in Design (PGDesign), in the School of Engineering of the Federal University of Rio Grande do Sul (UFRGS), in Porto Alegre (Brazil). She received a Universal research grant from National Council for Scientific and Technological Development (CNPq) in the area of contemporary jewelry and materials characterization and recovery. Her main research topics include bionics, sustainability, contemporary jewelry, materials recycling, and product design. She is associated with the Design and Technological Innovations Research Group (DIT/CNPq) at UFSM. mariana.cidade@ufsm.br

(3) Branca Freitas de Oliveira. Associate professor in the Department of Design and Graphic Expression at the Federal University of Rio Grande do Sul (UFRGS), in Porto Alegre (Brazil). Branca Oliveira received her M.Sc. and her Ph.D. in Civil Engineering in the Graduate Program of Civil Engineering (PPGEC), in the School of Engineering of UFRGS, and completed her post-doc in the same University. She is a Level 2 fellowship of Research Productivity (PQ) granted by the National Council for Scientific and Technological Development (CNPq). Has experience in the areas of Civil and Mechanical Engineering, with emphasis on structural mechanics, acting mainly on the following themes: new materials, composite materials, finite elements, constitutive models, failure, aging, damage, viscoelasticity, and plasticity. She is associated with the Design and Computer Simulation Research Group (DSC/CNPq). branca@ufrgs.br

(4) Jorge Ernesto de Araujo Mariath. Full professor (retired) in the Graduate Program of Botany (PPGBot) at the Federal University of Rio Grande do Sul (UFRGS), in Porto Alegre (Brazil). Jorge Mariath received his M.Sc. in Botany at UFRGS and his Ph.D. in Biological Sciences (Botany) in São Paulo University (USP). He is a Level 2 fellowship of Research Productivity (PQ) granted by the National Council for Scientific and Technological Development (CNPq). He was Director of the Biosciences Institute at UFRGS and was the founder of the Plant Anatomy Laboratory (LAVeg/UFRGS). Has experience in the area of Botany, subarea Plant Morphology, with emphasis on Plant Anatomy and Embryology, acting mainly on the following themes: Rubiaceae, Aquifoliaceae, Leguminosae, Bromeliaceae, Passifloraceae, and Iridaceae. jorge.mariath@ufrgs.br 


\section{Introduction}

Bionics is a branch of project development in which nature is used as a basic ground for inspiration, being applied in design, architecture, and engineering solutions (Roth, 1983). In bionic design, the desired characteristics have their variables simplified, and they are evaluated regarding their structural, functional, or aesthetical characteristics prior to application (Cidade et al., 2015; Kindlein Júnior \& Guanabara, 2005). Essentially, bionics requires a transdisciplinary approach to guarantee the studied features are correctly understood and tested, by means of combining a multitude of professionals with different skills and formations. When working with biological samples, for example, the comprehension process of the analyzed subject demands the trained eyes and expertise of a biologist, whereas applying it in a structure design calls for the acting presence of an engineer (Palombini, 2020). On the other hand, a design-trained professional can act as a medium for conducting the workflow of the project, particularly regarding the definition of a common language between all specialists, and one of the main areas which a designer can contribute with is the use of new 3D technologies (Palombini et al., 2017; 2018).

Traditionally, bionic designs have been developing with the assist of several observation techniques, ranging ever since from regular photography to state-of-the-art, high-resolution biomedical imaging (Akhtar et al., 2006; Kindlein Júnior \& Guanabara, 2005; Palombini et al., 2016). In general, designers must learn to navigate through a variety of technologies available to find the most appropriate way to investigate a certain natural characteristic. From simple to intricate projects, the investigation tools can be explored independently from the complexity level of the chosen sample (Hübschen et al., 2016). However, the knowledge of a specialized professional should also be a starting point in the selection of the more suitable technique to be used.

Brodersen \& Roddy (2016) state that the future of 3D viewing in botany lies within the merging of multiple techniques. Recent advances in biological studies are becoming even more dependent on 3D technologies in a way to allow more complex analyses either with higher resolutions or with the use of computational simulations (Palombini et al., 2017). For instance, we may cite the innovations provided by new technologies such as X-ray imaging and numerical analyses that are defining how biological subjects are being studied (Boyd, 2009; Hanke et al., 2016). Moreover, by increasing the complexity in which biological features are being studied, new discoveries are being made that can even contribute to some classical and well-established fields of science, such as botany.

This paper presents an overview of the evolution of observation and analysis techniques and their impact on both innovative bioinspired designs and new findings for plant sciences. Initially, we discuss case studies from the literature where the evolution of techniques has contributed to some significant breakthroughs in botany, in particular how 3D image-based analyses are redefining aspects in plant morphology and anatomy, and even providing new interpretations of the structure and function of plant characteristics. Finally, examples of bioinspired projects conceptualized by students of Bionics are presented where different methods in the observation and analysis steps were employed during the creative process, resulting in an array of applications and details, ranging from Surface to Product design. 


\section{From light microscopy to X-ray microtomography in botany}

The evolution of observation methods is tightly bound to the history of botany. Since the first adaptations of a compound microscope in the late XVI century by Zacharias Janssen (Bolam, 1973), and a candle-based light microscope by Robert Hooke in the XVII century, where the first illustrations of cork were made coining the name "cell" (Evert \& Eichhorn, 2006), observation techniques helped to define the very basis of plant anatomy and morphology. Fundamentally, those fields are related to the study of morphological traits of plants, through observation and interpretation, using multiple scales of magnification (Palombini et al., 2017). From those observations, a researcher can infer descriptions about several functional aspects of the sample. And according to Brodersen \& Roddy (2016, p. 184), the resulting observations of the first developed microscopes "were revolutionary and radically altered contemporary thinking on the structure and function of living organisms". Examples of different techniques for visualization in botany are shown in Figure 1, with samples of Maté (Ilex paraguariensis - Aquifoliaceae).
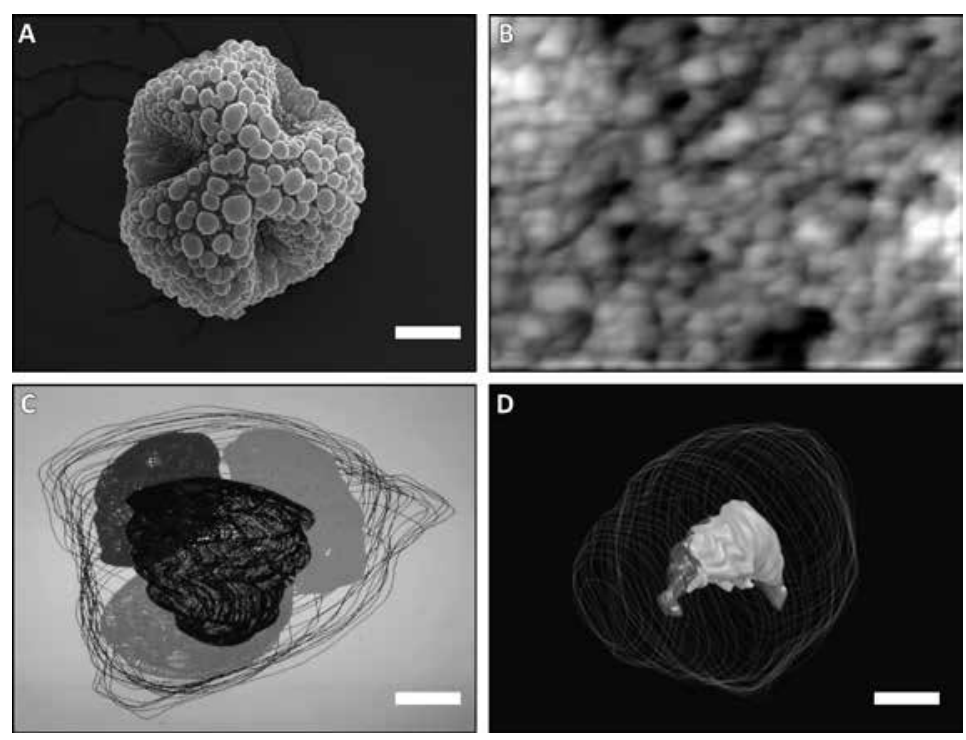

Figure 1. Different observation techniques employed in samples of Maté (I. paraguariensis): (A) Scanning Electron Microscopy (SEM) of a pollen grain (Rinaldo Santos \& Jorge E. A. Mariath) and (B) Atomic Force Microscopy (AFM) of the pollen sporoderm in nanoscale magnification (Ricardo Santos, Rinaldo Santos \& Jorge E. A. Mariath); 3D reconstructions based on serial microscopic sections of the (C) tetrad of microspores and the (D) male germ unit. Scale bars: $A, D=5 \mu \mathrm{m} ; C=4 \mu \mathrm{m}$. 
The need for entering the three-dimensional realm in botany started soon after, with pioneer works by Nehemiah Grew and Marcello Malpighi in the XVII century, where they recognized the necessity of conceptualizing plants in 3D due to the distinct spatial relations in the microscopic scale (Brodersen \& Roddy, 2016). During the following centuries, technology has advanced to allow even more microstructural details to be distinguished, substantiating statements for new descriptions. With the advent of photography and optical illumination systems, new recording methods surge, facilitating the interpretation of the analyzed features. Later, with the earliest recognized work by Max Knoll, in 1935, describing the concept of a Scanning Electron Microscopy (SEM), and the following studies in the 1940s and 1950s (Goldstein et al., 2003), the technique further increases the ability to study details and fine structures, such as the example of Figure 1A. Even though SEM demanded specific methods for sample preparation (Anderson, 1951), the technique became one of the most important pieces of science equipment for the study of materials up to the present day (Callister \& Rethwisch, 2012), However, the details of microstructures in SEM still required trained eyes in order to reconstruct and fully visualize the observed specimen volumetrically, in 3D (Heywood, 1969). More recently, preliminary works employing Atomic Force Microscopy (AFM) were published in the mid-1990s, mainly focusing on the topography of pollen grains (Demanet \& Sankar, 1996; Rowley et al., 1995)to our knowledge, non-contact atomic force microscopy (AFM. However, the authors stated that despite the high resolution, the 3D presentation of the surface, and the absence of specific preparation methods, generally AFM was still limited by its depth of field. One example of AFM is shown in Figure $1 B$.

Basing on serially sectioned biological materials, some papers have improved the visualization of fine structures by combing them with newer 3D software, as showed in the examples of Figures 1C and 1D. For instance, Kuhn \& Mariath (2014) showed one of literature's first 3D reconstructions of "Brazilian pine" pollen (Araucaria angustifolia Araucariaceae), highlighting new aspects of its reproductive morphology. Using a similar approach, Fagundes \& Mariath (2014) revealed high-resolution details of the female gametophyte of a bromeliad (Billbergia nutans - Bromeliaceae). Stained vascular bundles were also digitalized as a series of cross-sections to reveal the branching morphology of the stem of an arborescent monocotyledon (Dracaena reflexa - Dracaenaceae), showing complex ramifications when reconstructed in 3D (Haushahn et al., 2014). However, despite allowing a new and interactive visualization of the internal structures, serial sectioning-based methods are still limited by physically cutting the sample, thus hindering the integrity of the final 3D model, particularly when dealing with delicate specimen.

Following the technological advances of 3D imaging, the use of X-ray-based technologies opened the possibilities for in-depth and non-invasive analysis of samples, particularly with the application of X-ray microtomography $(\mu \mathrm{CT})$, in the late XX century (Palombini, 2020). Initially focused on medical-related subjects, $\mu$ CT started to spread to multiple fields, due to its high-resolution and powerful 3D capabilities (Hanke et al., 2016). Generally, the technique uses sequential radioprojectios, in the X-ray spectrum, to digitalize a sample, and to reconstruct it with mathematical algorithms into a $3 \mathrm{D}$ solid, that can be exported and treated as a bulk volume, as opposed to a superficial volume of the previously mentioned techniques (Palombini et al., 2016). As a result, images using $\mu \mathrm{CT}$ 
can be digitally sectioned in virtually any spatial plane, without damaging delicate tissues (Palombini et al., 2017; 2018).

In the past few years, investigations using $\mu \mathrm{CT}$ have finally reached plant sciences and related areas, leading to an increasing number of published papers that explore such tools (See Figure 2). Recently, some papers have allowed the exploration of never-before-seen characteristics of plant anatomy and morphology using $\mu \mathrm{CT}$. For instance, Palombini et al. (2020) revealed the complex arrangement of the vascular bundles of bamboo (Bambusa tuldoides - Poaceae) in the nodal region of the stem. In addition to morphological studies and qualitative investigations, $\mu \mathrm{CT}$ also allows digitalized samples to be analyzed numerically, by segmenting and binarizing the data (Palombini, 2020). As an example, Nogueira et al. (2017) used $\mu \mathrm{CT}$ to reveal details of the inflorescence-tank of a bromeliad specimen (Nidularium innocentii - Bromeliaceae), including the determination of its apparent volume, given as milliliters.

More recently, a new type of investigation took advantage of an important characteristic of $\mu$ CT-based models by allowing the evaluation of a variety of aspects in a given biological sample. 3D models originated from X-ray microtomography reconstructions have been employed as a base model for Finite Element Analysis (FEA) in many fields of science. Initially focused on engineering projects, FEA consists of a mathematical method of discretizing some given geometry, which was initially considered 'infinite' or continuous, into a 'finite' set of smaller elements, to permit the computational simulation of real physic-mechanical conditions (Zienkiewicz et al., 2013). However, instead of using traditional CAD-based objects, as in engineering projects, $\mu \mathrm{CT}$ models can be exported and discretized to be used in FEA, taking advantage of their realistic geometry (Boyd, 2009; Palombini, Lautert, et al., 2020). As a result, biological 3D models can now be investigated in silico using several environmental conditions, ranging from more conventional structural analyses to physical studies, leading to important discoveries.

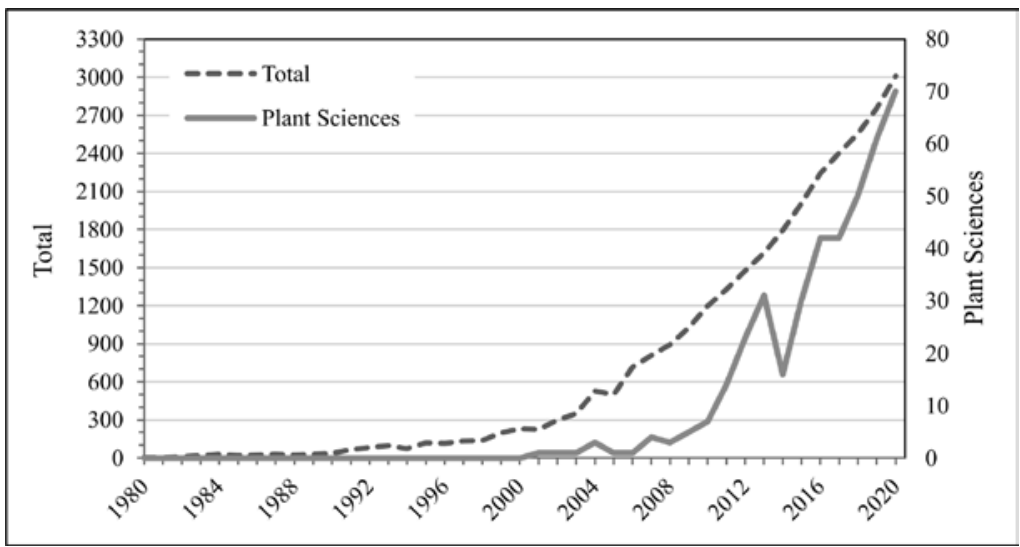

Figure 2. Number of papers registered in the Web of Science ${ }^{\mathrm{Ts}}$ platform that uses X-Ray microtomography, from 1980 to 2020, regarding Plant Sciences and related areas, and all other research fields (Total). 
Some recent papers can be cited as examples of $\mu$ CT-based FEA which contributed to new interpretations for known plant structures. For instance, Palombini et al. (2016) used a high-resolution $\mu \mathrm{CT}$ model of a stem region of a bamboo (B. tuldoides) in a static compressive FEA and verified that the parenchyma -which until then was not considered a mechanically relevant tissue in the plant- acts as a matrix in a composite analogy, by distributing stress along all fibers and contributing to the plant's overall structural integrity. Forell et al. (2015) virtually analyzed multiple breeding strategies to modify the stalk characteristics of maize (Zea mays - Poaceae), using a $\mu$ CT-derived model in an FEA, to prevent lodging and increase crop yielding. Nogueira et al. (2019) studied the thermal role of the inflorescence-tank of a bromeliad specimen $(N$. innocentii) by using literature's first $\mu \mathrm{CT}$-based, heat transfer FEA of a biological sample. Authors simulated one day of a heating and cooling environment in the plant, with and without the presence of water inside the inflorescence. They verified that the tank works as a thermal regulator, instead of a simple hydration source, by preventing internal structures to rapidly change temperature, which tends to cause severe injuries in the plant.

\section{Bionics as a function of observation and analysis techniques}

As shown, several technologies of observation and analysis have evolved and matured for application in botany as well as in many other fields of science, cleaning out paths that lead to newer discoveries. As a result, bioinspired projects can benefit from a variety of techniques to explore a given biological sample. An example is the work of Palombini et al. (2020) in which a $\mu$ CT of bamboo (B. tuldoides) was used to assess the overall geometry of individual vascular bundles, in order to be applied in the design of a bionic thin-walled structure, aimed at energy absorption. Authors verified that the fiber bundles' shape is a newly discovered feature of the plant that contributes to its stiffness and strength, and therefore can be included in the design of innovative bamboo-inspired structures.

Designers should be familiar with a range of observation equipment, being them either complex or simple options, as a way of knowing the most appropriate choices for a giving bionic project. Likewise, having the presence of researchers from different areas is a main step in the bionics methodology to study and analyze a biological characteristic. Unfortunately, due to obvious economical or geographical reasons, using state-of-the-art equipment in a bionic design is not always possible, neither in the industry nor in the academy. The lack of infrastructure or specialized personal may be a limiting factor for some techniques to be universally available, particularly in the case of the teaching of Bionics. Nevertheless, students can always explore ongoing or already published specialized studies that cover more advanced techniques in bionics, such as $\mu \mathrm{CT}$. Besides, working with more feasible or available tools can be especially important for understanding the bionic design process by the student.

Although significant progress has been made in terms of optics and functions in the last centuries, light microscopy (LM) is a classical technique for observing small details in biological samples, as seen in the previous topic, and it is still a key method in many studies. 
As a consequence, the ubiquitous presence of LM in schools and universities turned it into an essential tool for the teaching of several disciplines, including bionics. As examples, we present some works of undergraduate students of the discipline of Bionics from the Department of Industrial Design of the Federal University of Santa Maria (DI/UFSM) that used either LM or $\mu \mathrm{CT}$ to develop conceptual designs, such as seen in the patterns in Figure 3, by student Christian Cambruzzi da Silva.

The pattern developed by the student in Figure 3 started by exploring the use of LM in a pinewood sample (Pinus sp.-Pinaceae), naturally blue-stained by a fungus, where some visual characteristics in the surface were delineated and defined, such as the wood grains and the knot. Those features were parametrized, as shown in the first row, by means of simplifying the main visual aspects and vectorizing them, i.e., making them numerically scalable to different sizes. Next, patterns with different color variations were created, as seen in the second row. In the third row, the student presents different applications of the pattern, following the principles of surface design (Rüthschilling, 2008).

Generally, one of the main differences from the conceptual design of a product over a surface pattern is the inclusion of some functionality in the project. Instead of covering purely aesthetic features, such as the pattern presented in Figure 3, the application of the bioinspired characteristic focused on exploring the geometry of the examined natural material in terms of potential mechanisms, such as movement, path, and articulated systems. In the design presented in Figure 4, student Eduardo Rocha Sartori Sendtko developed an automatic conceptual watering vase equipment. In this example, the student based his project on the work of Nogueira et al. (2017), where the authors used a $\mu$ CT to scan the inflorescence-tank of a bromeliad specimen ( $N$. innocentii). The accumulation of water in the tank of the bromeliad inspired the creation of a container above the vase, which could slowly drip on the plant, over a controlled periodic time. The main objective of the concept was to allow an automatic watering of a decorative or food plant giving a set time defined by the user.

As mentioned before, $\mathrm{X}$-ray microtomography is a rather expensive modern technique for visualizing plants in $3 \mathrm{D}$ and in high-resolution. If utilizing $\mu \mathrm{CT}$ with a research purpose can many times be considered not feasible on a given budget, employing it in a bionic design would seem almost inconceivable. However, designers should also consider using some previous scientific works, where the technique has already been used, as a source for biological data and inspiration, such as the case of the conceptual watering vase. 

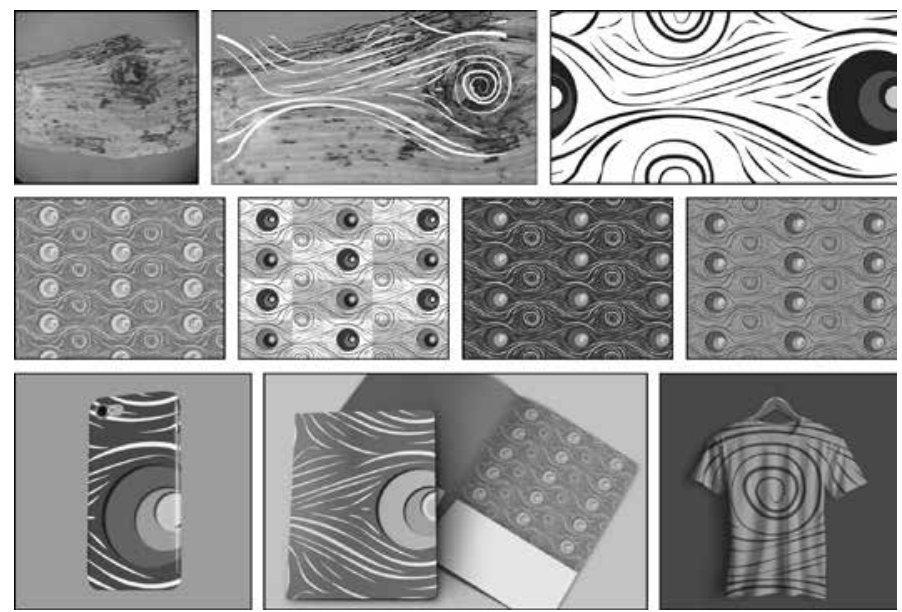

3
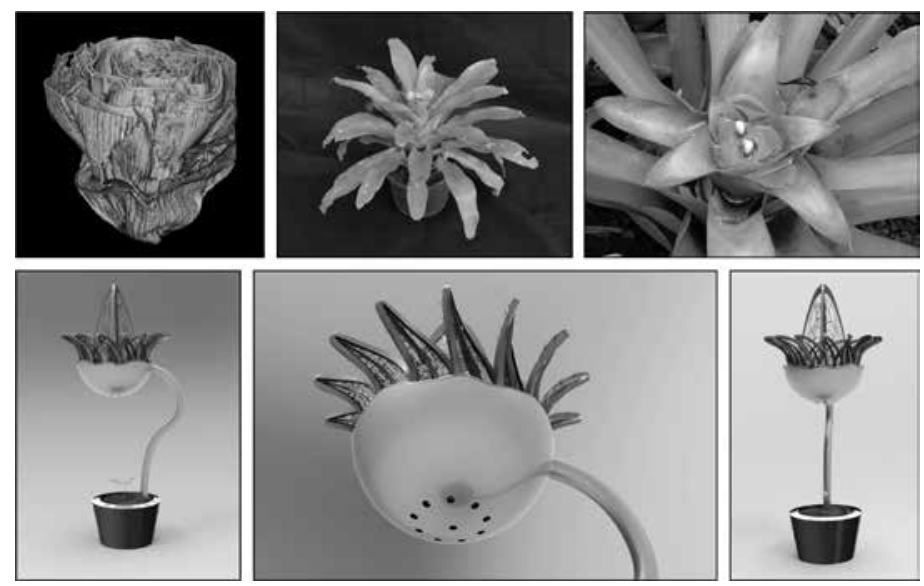

4

Figure 3. Development of a pattern bioinspired in wood, by student Christian Cambruzzi da Silva. Figure 4. Conceptual automatic watering vase by student Eduardo Rocha Sartori Sendtko, inspired by the work of Nogueira et al. (2017). 


\section{Conclusions}

In the last century, many new observation and analysis techniques have been developed, accelerating the discovery of new important characteristics of nature, contributing even to classic disciplines, such as plant anatomy and morphology. From the early stages of light microscopy to the latest X-ray microtomography equipment and Finite Element Analysis, those tools were and still are essential to the comprehension of such complex and fascinating materials. Besides, as a consequence, designers can take advantage of this new era of discoveries to induce new creative processes that lead to bionic and bioinspired projects for a range of applications.

By having a greater variety of technologies, and combining them appropriately, researchers can improve their field of view, by assessing morphological characteristics from the macro to the nanometric scale, from the surface to the bulk volume, and from qualitative to structural and physical analyses. The presence of a transdisciplinary team, composed of investigators with different training areas is a key part of this process. Scientists with different backgrounds, such as designers, biologists, and engineers can greatly contribute to innovation in investigation methods towards new findings. Moreover, such findings lead to new applications in bionic projects which, on the other hand, always requires the presence of an equally multidisciplinary team for the studied characteristic to be correctly interpreted, evaluated, and used.

Lastly, besides the direct application in bioinspired designs, highlighting the impact of having access to some observation techniques for bionic students is crucial. At any level of complexity, ever since LM, SEM, or $\mu \mathrm{CT}$, such equipment not only contributes to new perspectives on observing a certain sample but leads to a fascination and excitement in the students for the development of the creative process itself. Hence, bionics and traditional scientific fields like botany should be viewed as the two sides of the same arrow towards new discoveries and breakthroughs.

\section{Acknowledgments}

Authors thank Prof. Dr. João Marcelo Santos de Oliveira and the Structural Botany Laboratory from the Federal University of Santa Maria (UFSM) for the availability and assistance with the microscopy equipment used by the students. We are also thankful to the Plant Anatomy Laboratory (LAVeg) from the Federal University of Rio Grande do Sul (UFRGS) for the kind availability of micrographs.

\section{References}

Akhtar, R., Eichhorn, S. J., \& Mummery, P. M. (2006). Microstructure-based Finite Element Modelling and Characterisation of Bovine Trabecular Bone. Journal of Bionic Engineering, 3(1), 3-9. https://doi.org/10.1016/S1672-6529(06)60001-2 
Anderson, T. F. (1951). Techniques for the preservaation of three-dimensional structure in preparing specimens for the electron microscope ${ }^{\star}$. Transactions of the New York Academy of Sciences, 13(4 Series II), 130-134. https://doi.org/10.1111/j.2164-0947.1951.tb01007.x

Bolam, J. (1973). The botanical works of Nehemiah Grew, F. R. S. (1641-1712). Notes and Records of the Royal Society of London, 27(2), 219-231. https://doi.org/10.1098/ rsnr.1973.0017

Boyd, S. K. (2009). Image-Based Finite Element Analysis. In Advanced Imaging in Biology and Medicine (pp. 301-318). Springer Berlin Heidelberg. https://doi.org/10.1007/9783-540-68993-5_14

Brodersen, C. R., \& Roddy, A. B. (2016). New frontiers in the three-dimensional visualization of plant structure and function. American Journal of Botany, 103(2), 184-188. https:// doi.org/10.3732/ajb.1500532

Callister, W. D., \& Rethwisch, D. G. (2012). Fundamentals of Materials Science and Engineering : An Integrated Approach (4th ed.). John Wiley \& Sons, Inc.

Cidade, M. K., Palombini, F. L., \& Kindlein Júnior, W. (2015). Biônica como processo criativo : microestrutura do bambu como metáfora gráfica no design de joias contemporâneas. Revista Educação Gráfica, 19(1), 91-103.

Demanet, C. M., \& Sankar, K. V. (1996). Atomic force microscopy images of a pollen grain: A preliminary study. South African Journal of Botany, 62(4), 221-223. https://doi. org/10.1016/S0254-6299(15)30640-2

Evert, R. F., \& Eichhorn, S. E. (2006). Esau's plant anatomy : meristems, cells, and tissues of the plant body: their structure, function, and development. John Wiley \& Sons, Inc. https:// books.google.com/books?id=0DhEBA5xgbkC\&pgis=1

Fagundes, N. F., \& Mariath, J. E. de A. (2014). Ovule ontogeny in Billbergia nutans in the evolutionary context of Bromeliaceae (Poales). Plant Systematics and Evolution, 300(6), 1323-1336. https://doi.org/10.1007/s00606-013-0964-x

Forell, G. Von, Robertson, D., Lee, S. Y., \& Cook, D. D. (2015). Preventing lodging in bioenergy crops: a biomechanical analysis of maize stalks suggests a new approach. Journal of Experimental Botany, 66(14), 4367-4371. https://doi.org/10.1093/jxb/erv108

Goldstein, J., Newbury, D. E., Joy, D. C., Lyman, C. E., Echlin, P., Lifshin, E., Sawyer, L., \& Michael, J. R. (2003). Scanning electron microscopy and X-ray microanalysis (3rd ed.). Springer Science \& Business Media.

Hanke, R., Fuchs, T., Salamon, M., \& Zabler, S. (2016). X-ray microtomography for materials characterization. In G. Hübschen, I. Altpeter, R. Tschuncky, \& H.-G. Herrmann (Eds.), Materials characterization using Nondestructive Evaluation (NDE) methods (pp. 45-79). Woodhead. https://doi.org/10.1016/B978-0-08-100040-3.00003-1

Haushahn, T., Speck, T., \& Masselter, T. (2014). Branching morphology of decapitated arborescent monocotyledons with secondary growth. American Journal of Botany, 101(5), 754-763. https://doi.org/10.3732/ajb.1300448

Heywood, V.H. (1969). Scanning electron microscopy in the study of plant materials. Micron (1969), 1(1), 1-14. https://doi.org/10.1016/0047-7206(69)90002-8

Hübschen, G., Altpeter, I., Tschuncky, R., \& Herrmann, H.-G. (Eds.). (2016). Materials characterization using Nondestructive Evaluation (NDE) methods. Woodhead. 
Kindlein Júnior, W., \& Guanabara, A. S. (2005). Methodology for product design based on the study of bionics. Materials \& Design, 26(2), 149-155. https://doi.org/10.1016/j. matdes.2004.05.009

Kuhn, S. A., \& Mariath, J. E. de A. (2014). Reproductive biology of the "Brazilian pine" (Araucaria angustifolia - Araucariaceae): Development of microspores and microgametophytes. Flora - Morphology, Distribution, Functional Ecology of Plants, 209(5-6), 290-298. https://doi.org/10.1016/j.flora.2014.02.009

Nogueira, Fernanda M., Palombini, F. L., Kuhn, S. A., Oliveira, B. F., \& Mariath, J. E. A. (2019). Heat transfer in the tank-inflorescence of Nidularium innocentii (Bromeliaceae): Experimental and finite element analysis based on X-ray microtomography. Micron, 124, 102714. https://doi.org/10.1016/j.micron.2019.102714

Nogueira, Fernanda Mayara, Kuhn, S. A., Palombini, F. L., Rua, G. H., Andrello, A. C., Appoloni, C. R., \& Mariath, J. E. A. (2017). Tank-inflorescence in Nidularium innocentii (Bromeliaceae): three-dimensional model and development. Botanical Journal of the Linnean Society, 185(3), 413-424. https://doi.org/10.1093/botlinnean/box059

Palombini, F. L. (2020). Diretrizes para pesquisas em materiais vegetais com análises por elementos finitos baseadas em microtomografia de raios $X$ e implicações para projetos de biônica em design e engenharia. (Tese de Doutorado. Programa de Pós-Graduação em Design. Universidade Federal do Rio Grande do Sul, Porto Alegre, Brasil).

Palombini, F. L., Kindlein Junior, W., Oliveira, B. F. de, \& Mariath, J. E. de A. (2016). Bionics and design: $3 \mathrm{D}$ microstructural characterization and numerical analysis of bamboo based on X-ray microtomography. Materials Characterization, 120, 357-368. https://doi. org/10.1016/j.matchar.2016.09.022

Palombini, F. L., Kindlein Junior, W., Oliveira, B. F. de, \& Mariath, J. E. de A. (2018). Materiais e Biônica: sob a Ótica da Análise de Elementos Finitos Baseada em Imagens de Microtomografia de Raios X. In A. J. V. Arruda (Ed.), Métodos e Processos em Biônica e Biomimética: a Revolução Tecnológica pela Natureza (pp. 245-260). Editora Blucher. https://doi.org/10.5151/9788580393491-15

Palombini, F. L., Kindlein Júnior, W., Silva, F. P. da, \& Mariath, J. E. de A. (2017). Design, biônica e novos paradigmas: uso de tecnologias 3D para análise e caracterização aplicadas em anatomia vegetal. Design e Tecnologia, 7(13), 46. https://doi.org/10.23972/ det2017iss13pp46-56

Palombini, F. L., Lautert, E. L., Mariath, J. E. de A., \& de Oliveira, B. F. (2020). Combining numerical models and discretizing methods in the analysis of bamboo parenchyma using finite element analysis based on X-ray microtomography. Wood Science and Technology, 54(1), 161-186. https://doi.org/10.1007/s00226-019-01146-4

Palombini, F. L., Linden, J. C. de S. van der, Mariath, J. E. de A., \& Oliveira, B. F. de. (2018). Design-Aided Science: o designer como promotor de tecnologias 3D para inovação em pesquisa científica. Revista Educação Gráfica, 22(3), 169-186.

Palombini, F. L., Mariath, J. E. de A., \& Oliveira, B. F. de. (2020). Bionic design of thinwalled structure based on the geometry of the vascular bundles of bamboo. Thin-Walled Structures, 155, 106936. https://doi.org/10.1016/j.tws.2020.106936

Palombini, F. L., Nogueira, F. M., Kindlein Junior, W., Paciornik, S., Mariath, J. E. de A., \& Oliveira, B. F. de. (2020). Biomimetic systems and design in the 3D characterization 
of the complex vascular system of bamboo node based on X-ray microtomography and finite element analysis. Journal of Materials Research, 35(8), 842-854. https://doi. org/10.1557/jmr.2019.117

Roth, R. R. (1983). The Foundation of Bionics. Perspectives in Biology and Medicine, 26(2), 229-242. https://doi.org/10.1353/pbm.1983.0005

Rowley, J. R., Flynn, J. J., \& Takahashi, M. (1995). Atomic Force Microscope Information on Pollen Exine Substructure in Nuphar. Botanica Acta, 108(4), 300-308. https://doi. org/10.1111/j.1438-8677.1995.tb00498.x

Rüthschilling, E. A. (2008). Design de Superficie. UFRGS.

Zienkiewicz, O. C., Taylor, R. L., \& Zhu, J.Z. (2013). The finite element method: its basis and fundamentals (7th ed.). Butterworth-Heinemann.

Resumen: Los logros recientes en diseños bioinspirados siguen de cerca los crecientes avances en las tecnologías de observación que son esenciales para comprender una estructura o sistema biológico y adaptarlos correctamente en un proyecto. Asimismo, diferentes áreas de disciplinas clásicas, como las ciencias vegetales, incluso se están reescribiendo gracias al avance de las nuevas tecnologías. Este artículo aborda el impacto que tiene el uso de tecnologías de observación en el desarrollo de la investigación botánica de vanguardia, así como sus aplicaciones en diseños biónicos. Desde microscopía óptica (LM) hasta microtomografía de rayos $\mathrm{X}(\mu \mathrm{CT})$, presentamos ejemplos de cómo múltiples tecnologías están contribuyendo a innovaciones y descubrimientos más recientes en morfología y anatomía de plantas, respondiendo preguntas importantes sobre estructura / función. Se discute la evolución de las tecnologías de observación, mostrando cómo están impactando la comprensión de múltiples características de las plantas y su consiguiente adaptación y uso en proyectos bioinspirados mediante ejemplos. Esencialmente, el enfoque transdisciplinario de conectar profesionales de múltiples campos se considera fundamental para el progreso obtenido tanto en biónica como en botánica. Al incluir nuevas tecnologías de observación en su flujo de trabajo de investigación, los diseñadores y botánicos podrían beneficiarse de diferentes perspectivas en la investigación y aplicación de sus hallazgos.

Palabras clave: Diseño - Tecnología - Biónica - Biomimética - Análisis de elementos finitos - Microtomografía de rayos X - Microscopía óptica - Anatomía vegetal - Morfología vegetal - Procesos creativos.

Resumo: Conquistas recentes em designs bioinspirados seguem de perto os avanços crescentes nas tecnologias de observação, que são essenciais para compreender uma estrutura ou sistema biológico e adaptá-los corretamente em um projeto. Da mesma forma, diferentes áreas de disciplinas clássicas, como as ciências das plantas, estão até mesmo sendo reescritas graças ao progresso de novas tecnologias. Este artigo aborda o impacto do uso de tecnologias de observação no desenvolvimento da pesquisa botânica de ponta, bem como em suas aplicações em projetos biônicos. Da microscopia de luz (LM) à microtomografia 
de raios-X $(\mu \mathrm{CT})$, apresentamos exemplos de como várias tecnologias estão contribuindo para inovações e novas descobertas em morfologia e anatomia vegetal, respondendo a questões importantes sobre estrutura / função. A evolução das tecnologias de observação é discutida, mostrando como elas estão impactando a compreensão das múltiplas características das plantas e sua consequente adaptação e uso em projetos bioinspirados por meio de exemplos. Essencialmente, a abordagem transdisciplinar de conectar profissionais de múltiplas áreas é considerada essencial para o progresso obtido tanto na biônica quanto na botânica. Incluindo novas tecnologias de observação em seu fluxo de trabalho de pesquisa, designers e botânicos podem se beneficiar de diferentes perspectivas na investigação e aplicação de suas descobertas.

Palavras chave: Design - Tecnologia - Biônica - Biomimética - Análise de elementos finitos - Microtomografia de raios X - Microscopia de luz - Anatomia vegetal - Morfologia vegetal - Processos criativos 